\title{
THE APPLICATION OF HIGH-GRADIENT MAGNETIC SEPARATION TO WATER TREATMENT BY MEANS OF CHEMICALLY PRECIPITATED MAGNETITE
}

\author{
V. HENCL AND P. MUCHA \\ Institute of Geotechnics, Czech Academy of Sciences, V Holešovičkách 41, \\ Prague 8, Czech Republic
}

(Received August 18, 1993)

\begin{abstract}
Conditions of high-gradient magnetic separation (HGMS) of chemically precipitated magnetite, prepared from a waste material of the titanium white production were studied. The magnetite was used as a sorption material for the treatment of water from the Vltava River. Detailed experimental research resulted in a proposal for a technology of water treatment, schematic description of which is presented. The results of HGMS of chemically precipitated magnetite together with those of water treatment are discussed.
\end{abstract}

\section{INTRODUCTION}

The procedure developed at CSIRO (Australia) has been described [1 - 3] for drinking water treatment, in which the generally used classical coagulating agents $\left(\mathrm{FeCl}_{3}, \mathrm{Al}_{2}\left(\mathrm{SO}_{4}\right)_{3}\right)$ were replaced by a suspension of finely ground and screened natural magnetite, onto the surface of which it is possible to capture impurities contained in the water.

Authors of this technique have offered an explanation of the mechanism of the magnetite action whereby a positive charge generated on the surface of a magnetite particle in acid environment enables the negatively charged particles of the impurities contained in the water to be captured on the surface of the magnetite particle. On the other hand, in alkaline environment the magnetite 
surface is charged negatively and thus repulsion of negatively charged particles from the magnetite surface occurs. The magnetite acts as an impurity adsorbent in acid environment, while as desorbent in alkaline medium. As a result of ferromagnetic properties of magnetite, magnetic separation can be used for its separation from the liquid phase. Authors of this procedure have preferred the use of natural magnetite due to the possibility of utilization of conventional electromagnetic separators for magnetite separation (of particle size of 5 to $10 \mu \mathrm{m}$ ). These separators are more advantageous because of lower capital and running costs compared to high-gradient magnetic separators which are required in the case of chemically precipitated magnetite.

It it the opinion of the authors of this contribution, based on practical experience, that preparation of natural magnetite of particle size of 5 to $10 \mu \mathrm{m}$ is rather complex and expensive, which has been confirmed by the authors of the CSIRO technique, by their estimate of the price of magnetite amounting to AUS\$100 per tonne. Moreover, the consumption of magnetite of $12 \mathrm{~g}$ per liter is rather high (low specific surface).

This is why the possibility was studied of utilization of chemically precipitated magnetite prepared from waste material, such as acid pickling steel bath, or waste ferrous sulphate arising from the production of titanium white. Conditions were studied under which its magnetic separation is feasible and thus also its regeneration and utilization for drinking water treatment. The results of the study are described in this paper.

\section{MATERIALS AND METHODS}

\section{Magnetite}

Magnetite used in the study was chemically prepared from both acid pickling steel bath obtained from East-Slovakian Iron Works, Slovakia, and waste $\mathrm{FeSO}_{4} \cdot 7 \mathrm{H}_{2} \mathrm{O}$ arising from the production of titanium white from ilmenite, obtained from the chemical plant in Přerov, Czech Republic.

The method of Okuda [4] was used for the preparation of magnetite. The principle of this procedure consists in precipitation of the $\mathrm{FeSO}_{4} \cdot 7 \mathrm{H}_{2} \mathrm{O}$ solution with $\mathrm{NaOH}$ 
solution at the $\mathrm{pH}$ value of up to 9 . $\mathrm{Fe}(\mathrm{OH})_{2}$ thus formed is then oxidised by the air oxygen at the temperature of 35 to $40^{\circ} \mathrm{C}$. The basic equation (1) of the magnetite formation from the $\mathrm{FeSO}_{4} \cdot 7 \mathrm{H}_{2} \mathrm{O}$ solution can be expressed as follows:

$$
3 \mathrm{FeSO}_{4} \cdot 7 \mathrm{H}_{2} \mathrm{O}+6 \mathrm{NaOH}+\frac{1}{2} \mathrm{O}_{2} \longrightarrow \mathrm{Fe}_{3} \mathrm{O}_{4}+3 \mathrm{Na}_{2} \mathrm{SO}_{4}+24 \mathrm{H}_{2} \mathrm{O}
$$

Very fine particles of magnetite are the reaction product and are aggregated due to the Earth magnetic field. After sedimentation a suspension of magnetite of density of 80 to $100 \mathrm{~g} / \ell$ is formed in 24 hours. Granulometric distribution of this product is shown in Table I. The settled suspension of magnetite was decanted several times with distilled water until the reaction for $\mathrm{SO}_{4}^{2-}$ was negative, the content of solid matter was determined and the prepared suspension was used for further experiments.

\section{Untreated Water}

Samples of the water from the Vltava River used as a starting material for the production of the drinking water in Prague were employed in the tests of water treatment with magnetite suspension. Typical composition of the water is given in Table II.

TABLE I Granulometric distribution of the magnetite suspension

\begin{tabular}{cc}
\hline Particle size $(\mu \mathrm{m})$ & Content $(\%)$ \\
\hline & \\
+6 & 0.5 \\
$3-4$ & 1.1 \\
$2-3$ & 1.6 \\
$1-2$ & 6.8 \\
$0.4-1$ & 35.7 \\
-0.4 & 54.3 \\
\hline
\end{tabular}


TABLE II Typical composition of water from the Vltava River

\begin{tabular}{lc}
\multicolumn{1}{c}{ Parameter } & Value \\
\hline $\begin{array}{l}\text { Colour } \mathrm{mg} / \ell \mathrm{Pt} \\
\text { Turbidity ZF }\end{array}$ & 40.0 \\
$\begin{array}{l}\text { Chemical consumption of } \\
\text { oxygen, } \mathrm{mg} / \ell \mathrm{O}_{2}\end{array}$ & 11.5 \\
Total $\mathrm{Fe}, \mathrm{mg} / \ell$ & 11.0 \\
$\mathrm{NO}_{2}^{-}, \mathrm{mg} / \ell$ & 0.23 \\
$\mathrm{NH}_{4}^{+}, \mathrm{mg} / \ell$ & 0.084 \\
$\mathrm{Mn}^{2+}, \mathrm{mg} / \ell$ & 0.23 \\
\end{tabular}

\section{Equipment for HGMS and Method of Experimentation}

The HGMS tests were carried out in a laboratory HGMS separator which consisted of iron-clad solenoid with controllable magnetic induction of up to 0.7 Tesla in working zone of volume of $1.6 \ell$ (depth $170 \mathrm{~mm}$, diameter $100 \mathrm{~mm}$ ). A matrix located in a chamber of cross-section of $28.6 \times 38.5 \mathrm{~mm}$ and height of $150 \mathrm{~mm}$ was inserted into the working zone. Sheets of expanded ferromagnetic steel of mesh dimensions of $7 \times 4 \mathrm{~mm}$ were used as the matrix. The expanded metal sheets of depth of $150 \mathrm{~mm}$ were arranged in staggered manner into a stack $150 \mathrm{~mm}$ high.

A suspension to be separated was fed from beneath from the feeding tank equipped with an agitator; the flowrate was controlled both by the change in hydrostatic pressure (the height of the tank) and by a suction device at the other end of the matrix chamber. Reverse flushing of the captured magnetic fraction was carried out by pressurised counter-current water. 
Flowrate of the suspension was determined by measuring the time of flow of $1000 \mathrm{~m} \ell$ of the filtrate through the matrix and calculated according to eq. (2):

$$
\mathrm{V}=\frac{1000}{\mathrm{~S} \epsilon \mathrm{t}}(\mathrm{m} / \mathrm{s})
$$

where $S$ is the matrix area $\left(\mathrm{m}^{2}\right), \epsilon$ is the porosity of the matrix (in case of the expanded metal matrix $\epsilon=0.87$ ), $t$ is the time of the flow (s).

The efficiency of the magnetite capture in the matrix was determined from the difference in the amounts of magnetite in the feed suspension and that captured in the matrix.

\section{Experimental Device and Procedures Used}

The same procedure was used for these experiments as that employed by the authors of the CSIRO technique $[1-3]$ under laboratory conditions. The suspension of chemically precipitated magnetite was at first agitated with a solution of alkali $\left(\mathrm{NaOH}\right.$ or $\left.\mathrm{Na}_{2} \mathrm{CO}_{3}\right)$, then decanted with water three times, and finally added to a sample of untreated water $(1 \ell), \mathrm{pH}$ of which was pre-adjusted by addition of the $\mathrm{H}_{2} \mathrm{SO}_{4}$ solution. The mixture was stirred and subsequently magnetic separation of magnetite was carried out and the water that passed through the matrix was analysed.

\section{EXPERIMENTAL}

\section{High-Gradient Magnetic Separation}

The main objective of magnetic separation is in this case the removal of particles of chemically precipitated magnetite as efficiently as possible, including the impurities upon its surface, captured from the aqueous phase. The achieved performance of capture not only directly influences the quality of eater treatment but also affects the economy of the process (losses of magnetite suspension). 
Based on the suggested research, the following parameters were found to influence decisively the efficiency of capture of particles of chemically precipitated magnetite in the matrix of the high-gradient magnetic separator:

- induction of the magnetic field

- specific matrix loading

- flowrate through the matrix.

Figure 1 shows the values of the capture efficiency as depending on the magnetic induction at three different flowrates of the suspension through the matrix, at specific matrix loading of $0.026 \mathrm{~g} / \mathrm{cm}^{3}$. It follows from the trend of the curves that the efficiency approaching 100 per cent can be achieved at a relatively wide range of flowrates at magnetic induction higher than $0.3 \mathrm{~T}$.

Flow velocity $[\mathrm{m} / \mathrm{s}]$

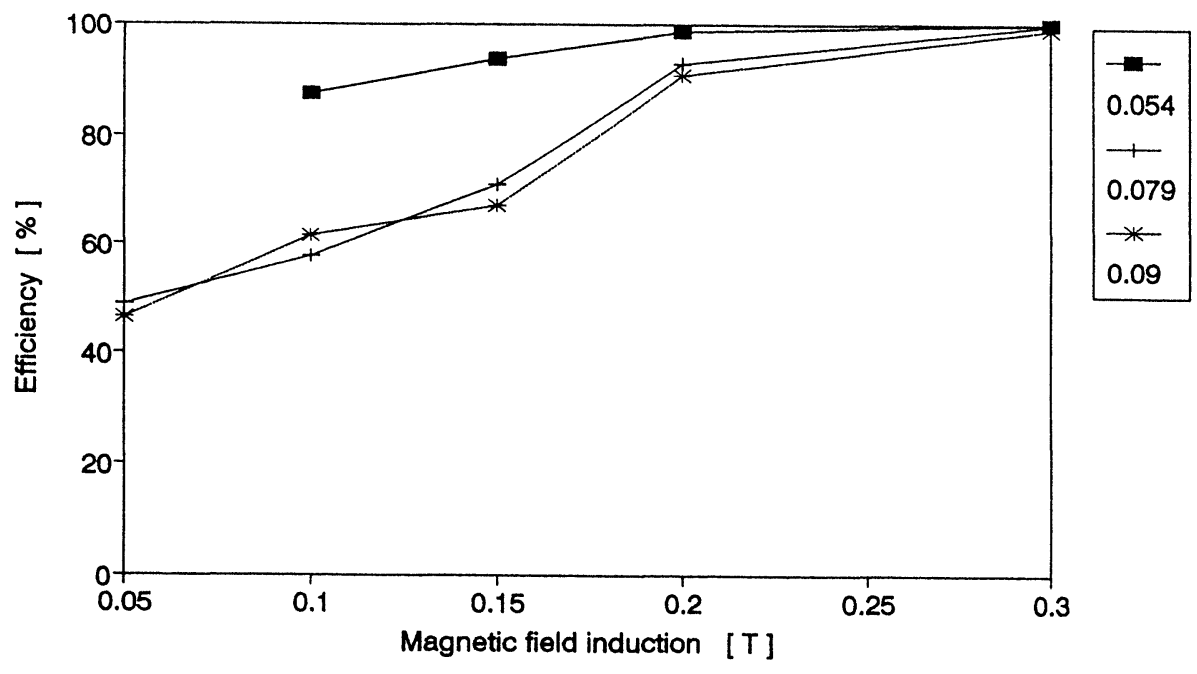

FIGURE 1 The efficiency of the magnetite capture as a function of magnetic induction

Figure 2 shows the dependence of the efficiency of the magnetite capture by the matrix on specific matrix loading, at magnetic induction of $0.2 \mathrm{~T}$ and flowrate of $0.08 \mathrm{~m} / \mathrm{s}$. 


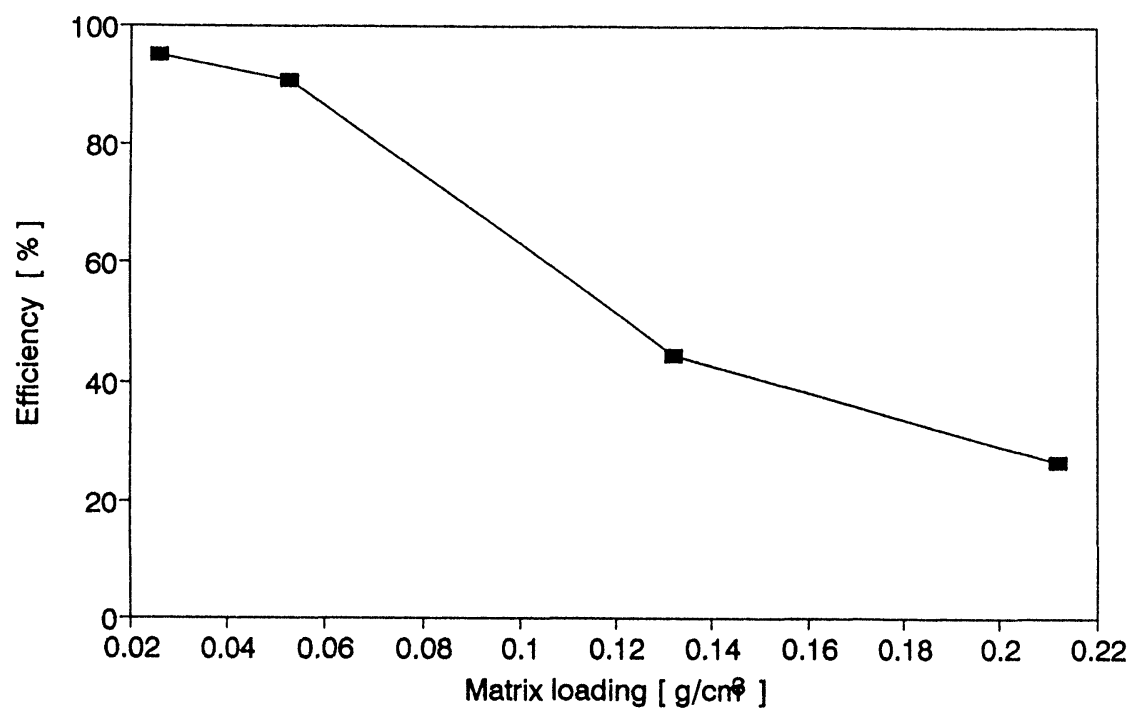

FIGURE 2 The efficiency of the magnetite capture as a function of matrix loading. $\mathrm{B}=0.2 \mathrm{~T}, \mathrm{v}=0.08 \mathrm{~m} / \mathrm{s}$.

Figure 3 depicts the dependence of the efficiency of the magnetite capture on the flowrate through matrix at three different values of magnetic induction $(0.15,0.2$ and $0.3 \mathrm{~T}$ ), and at specific matrix loading of $0.053 \mathrm{~g} / \mathrm{cm}^{3}$.

It is evident from the course of the curves in Fig. 2 that the capture efficiency is significantly influenced by the specific matrix loading. It drops from the value of $95.2 \%$ at the specific loading of $0.026 \mathrm{~g} / \mathrm{cm}^{3}$ and magnetic induction of $0.2 \mathrm{~T}$, to the value of $26.9 \%$ when the value of specific matrix loading was increased to 0.212 $\mathrm{g} / \mathrm{cm}^{3}$.

The increase in the flowrate through the matrix does not induce such a sharp drop in the efficiency of the magnetite capture in the matrix, as is demonstrated by the curves in Fig. 3. The higher the magnetic induction, the lower is this drop. On the basis of the results of these basic experiments it would be possible to specify 
optimum conditions for high-gradient magnetic separation of chemically precipitated magnetite for the selected matrix:

a. Magnetic induction $-0.5 \mathrm{~T}$

b. Specific matrix loading $-0.05 \mathrm{~g} / \mathrm{cm}^{3}$

c. Flowrate through the matrix $-10 \mathrm{~cm} / \mathrm{s}$.

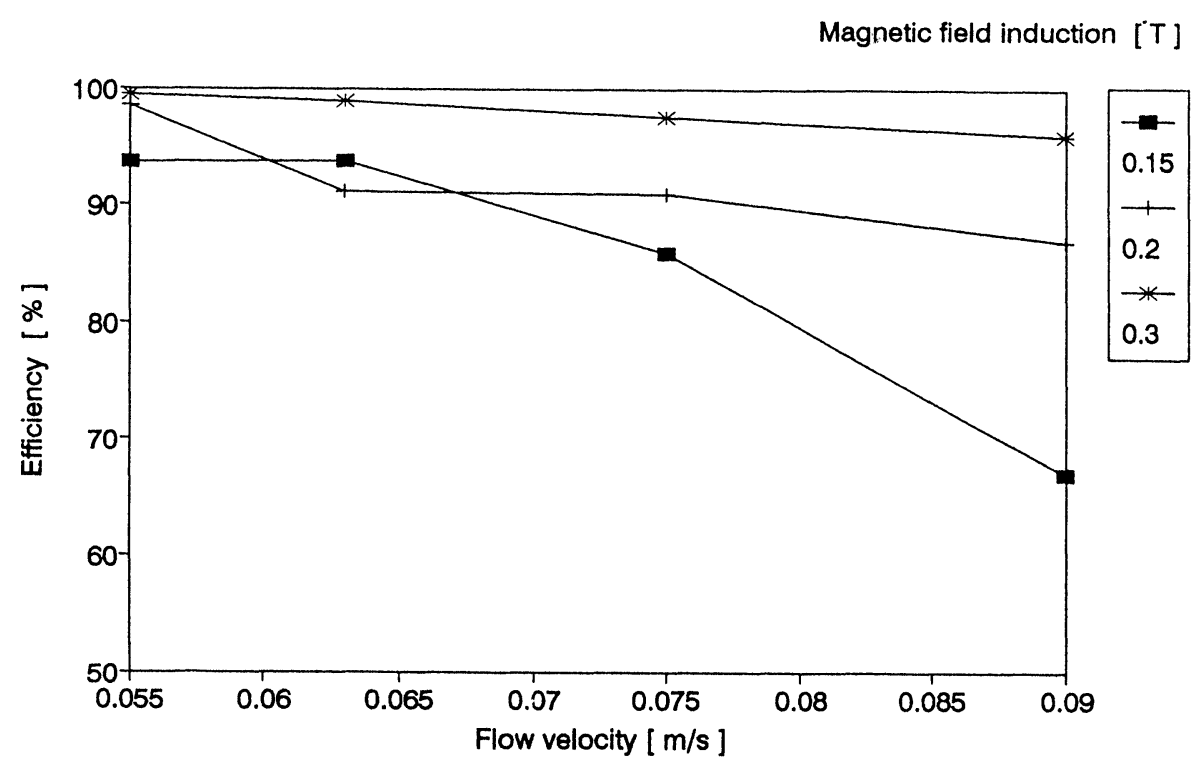

FIGURE 3 The efficiency of the magnetite capture on flow velocity. Specific matrix loading $0.053 \mathrm{~g} / \mathrm{cm}^{3}$.

These values are satisfactory even for industrial application because they allow a relatively high throughput of the separator to be achieved. Considering these experimental values, throughput of the HGMS separator with the working surface area of $1 \mathrm{~m}^{2}$ and depth of $0.15 \mathrm{~m}$ is $312 \mathrm{~m}^{3}$ of water per hour.

\section{Water Treatment with Chemically Precipitated Magnetite}

As in any technological process, this method of sorption of impurities contained in the water on the surface of magnetite or ferrite is affected by a series of parameters that should be optimised for specific conditions. These parameters are, above all, 
the $\mathrm{pH}$ of the untreated feed water, the time of agitation of untreated water with the suspension of magnetite or ferrite, number of revolutions of the agitator, the concentration and the type of the alkaline agent, the volume of suspension etc. A detailed research resulted in the technology of water treatment which is schematically shown in Figure 4.

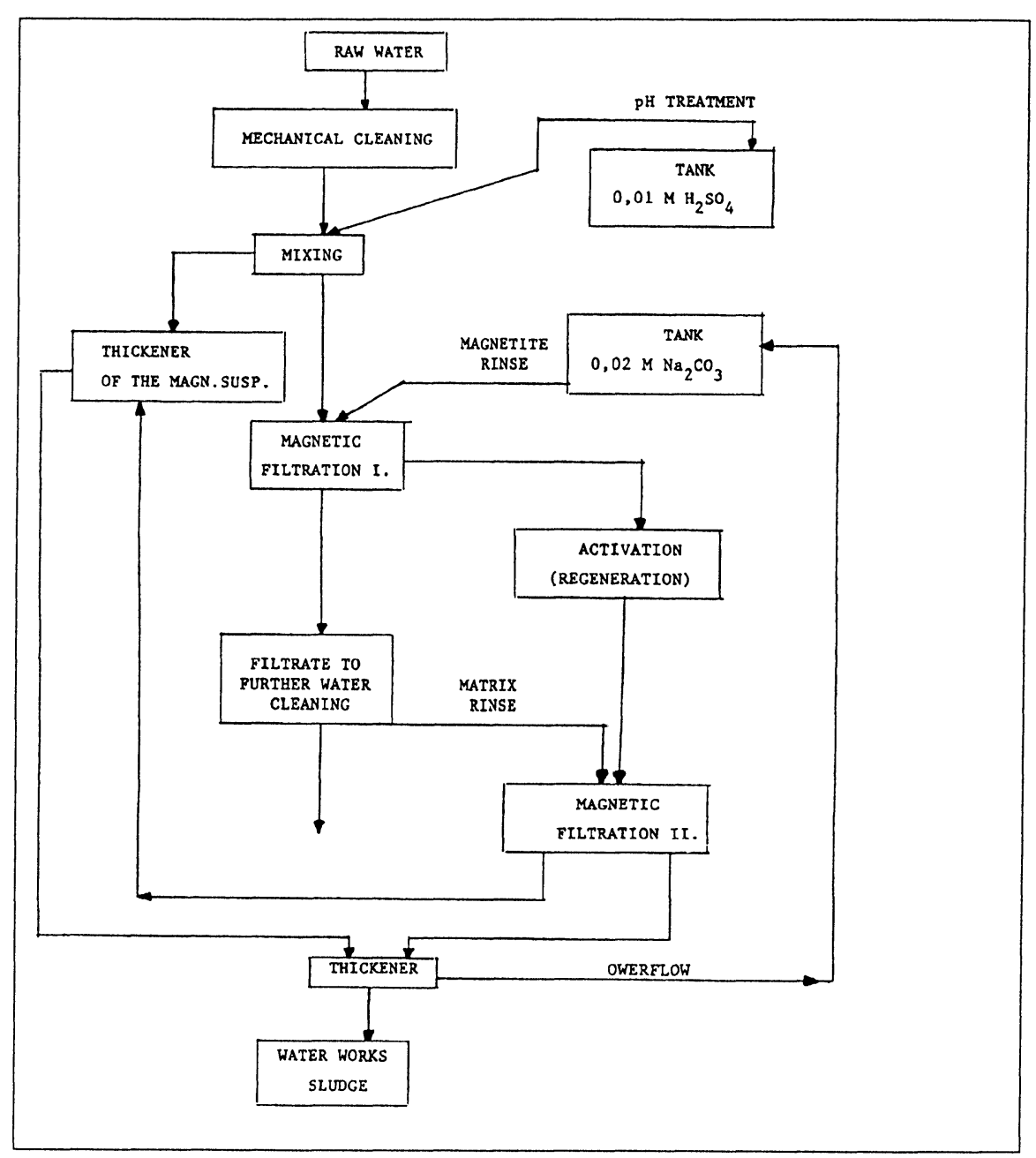

FIGURE 4 Flowsheet of water treatment using chemically precipitated magnetite 
The flowsheet was verified using samples of water from the Vltava River which is used as a source of water in Prague.

Untreated water is firstly mechanically purified (removal of coarse contaminants) before it reaches a mixing tank. The $\mathrm{pH}$ of the influent water should be adjusted by the $\mathrm{H}_{2} \mathrm{SO}_{4}$ solution (from the feeding tank) and the concentrated and regenerated suspension of the chemically precipitated magnetite is added from the thickener (it serves, at the same time, as a storage tank for the suspension).

After mixing for 20 minutes, the water is subjected to magnetic filtration in a high-gradient magnetic separator (magnetic induction $0.5 \mathrm{~T}$ ), where the magnetite is captured in the matrix. The filtrate from magnetic filtration is subjected to further water treatment which is conventionally required to achieve the standard of drinking water ( $\mathrm{pH}$ adjustment by lime, ozonisation, chlorination etc.). The final purification of the water by sand filtration may be omitted due to superior performance of magnetic filtration.

The magnetite from the separator matrix is flushed out by the solution of $0.05-$ $0.2 \mathrm{M} \mathrm{Na} \mathrm{Na}_{3}$ from the feed tank. The flushed suspension of magnetite is then stirred for 5 minutes in a mixing tank so that its regeneration could be achieved (repulsion of impurities from the surface of magnetite by a change of $\mathrm{pH}$ to alkaline range). The impurities are then separated in the next stage of high-gradient magnetic separation. Magnetite trapped in the matrix is rinsed with water in the magnetic field, then flushed in the absence of the field (from the filtrate of the first stage of magnetic filtration). The flush product is then returned to the thickener for the magnetic suspension. The overflow of the thickener is collected in a thickener for the water works sludge.

The filtrate from the second stage of magnetic filtration, containing large concentrations of $\mathrm{Na}_{2} \mathrm{CO}_{3}$ and the separated impurities from the water, is collected in a thickener of water works sludges, its overflow being returned to the feed tank of the solution of $\mathrm{Na}_{2} \mathrm{CO}_{3}$, whereby considerable savings in the consumption of $\mathrm{Na}_{2} \mathrm{CO}_{3}$ can be achieved. Its concentration can fluctuate within the range of $0.05-$ $0.2 \mathrm{M}$ at $\mathrm{pH} \approx 11$ and these concentration limits should be maintained by addition of $\mathrm{Na}_{2} \mathrm{CO}_{3}$. 


\section{RESULTS}

The sample of untreated water from the Vltava River with initial $\mathrm{pH}$ value of 6.9 , turbidity $12 \mathrm{ZF}$, colour $51 \mathrm{mg} / \ell \mathrm{Pt}$, COD (according to Kubel) $11.8 \mathrm{mg} / \ell \quad \mathrm{O}_{2}$, was adjusted to $\mathrm{pH}=5$ with $0.1 \mathrm{M} \mathrm{H}_{2} \mathrm{SO}_{4}$. After addition of a suspension of chemically precipitated magnetite from the pickling liquor $(5 \mathrm{~g} / \ell)$ generated in a solution of $0.05 \mathrm{M} \mathrm{Na}{ }_{2} \mathrm{CO}_{3}$ for 5 minutes, the magnetite suspension and untreated water were stirred for 15 minutes at $316 \mathrm{rpm}$.

Magnetic filtration was then applied at the magnetic induction of $0.5 \mathrm{~T}$ with the flowrate of $0.1 \mathrm{~m} / \mathrm{s}$ through the matrix. The results of two parallel tests are summarised in Table III. The colour of the water was reduced by $79 \%$ in average, turbidity by $85 \%$, COD by $76.4 \%, \mathrm{Fe}_{\text {total }}$ by $96 \%, \mathrm{NO}_{2}^{-}$by $29 \%, \mathrm{NH}_{4}^{+}$by $22 \%$ and Mn was removed fully. The number of psychrophilic bacteria decreased by $87 \%$, mezophyllic by $98.9 \%$ and coliforms by $99.85 \%$.

\section{CONCLUSIONS}

The newly proposed technique of water treatment by suspending chemically precipitated magnetite or ferrite is a potentially suitable alternative for industrial applications. for this purpose it is necessary to verify this process in a continuous pilot plant to obtain all necessary technical and economic data for its commercial application.

The main advantage of the new technique is the use of the waste material, e.g. the product of purification of the pickling liquor be precipitation of dissolved iron as ferrites. The possibility of magnetite regeneration and its easy separation from the treated water by high-gradient magnetic separation are other important advantages of the process. The fact that the water works sludge produced by this procedure does not contain residual metals, e.g. $\mathrm{Al}$ in the case of the use of the $\mathrm{Al}_{2}\left(\mathrm{SO}_{4}\right)_{3}$ solution as a coagulant in conventional treatment is a very important environmental feature of the new process.

The results of water treatment as demonstrated on the samples of water from the Vltava River are comparable to those obtained by treating the same samples by 
conventional techniques with coagulants based on $\mathrm{FeCl}_{3}$ or $\mathrm{Al}_{2}\left(\mathrm{SO}_{4}\right)_{3}$. The final water treatment by sand filters was not required. The rate of magnetic filtration is approximately 100 times higher than sedimentation of conventional coagulants.

TABLE III. Results of water treatment under optimised conditions.

\begin{tabular}{|c|c|c|c|c|}
\hline \multicolumn{5}{|c|}{ SAMPLE } \\
\hline & $\begin{array}{c}\text { Untreated } \\
\text { Vltava } \\
\text { Water } \\
\end{array}$ & $\begin{array}{l}1 \text { st } \\
\text { Test }\end{array}$ & $\begin{array}{l}\text { 2nd } \\
\text { Test }\end{array}$ & $\begin{array}{l}\text { Admissible } \\
\text { according } \\
\text { to CSN (*) } \\
\end{array}$ \\
\hline $\begin{array}{l}\text { Colour } \\
\mathrm{mg} / 1 \text { Pt }\end{array}$ & 40 & 8 & 9 & 20 \\
\hline $\begin{array}{l}\text { Turbidity } \\
\text { ZF }\end{array}$ & 11.5 & 2.0 & 1.5 & 5 \\
\hline $\begin{array}{l}\text { COD (Kubel) } \\
\mathrm{mg} / 1 \quad 02\end{array}$ & 11.5 & 2.0 & 1.5 & 3 \\
\hline $\begin{array}{l}\mathrm{Fe} \text { (total) } \\
\mathrm{mg} / \mathrm{l}\end{array}$ & 0.23 & 0.01 & 0.01 & 0.3 \\
\hline $\mathrm{NO} 2(\mathrm{mg} / \mathrm{l})$ & 0.084 & 0.06 & 0.06 & 0.1 \\
\hline NH4 $(\mathrm{mg} / \mathrm{l})$ & 0.23 & 0.18 & 0.23 & 0.5 \\
\hline Mn $\quad(m g / 1)$ & 0.26 & 0 & 0 & 0.1 \\
\hline $\begin{array}{l}\text { No. of psych- } \\
\text { rophylic } \\
\text { bacteria/ml }\end{array}$ & 1000 & 130 & 130 & 200 \\
\hline $\begin{array}{l}\text { No. of meso- } \\
\text { phylic } \\
\text { bacteria/ml }\end{array}$ & 800 & 11 & 11 & 20 \\
\hline $\begin{array}{l}\text { No. of coli- } \\
\text { form } \\
\text { bacteria/ml }\end{array}$ & 13 & 0.02 & 0.02 & 0 \\
\hline
\end{tabular}

${ }^{\mathrm{x}}$ According to the Czechoslovak Standard ČSN 757111 


\section{REFERENCES}

[1] N.J. Anderson et al.: Water Research 16 (1982), 1327

[2] N.J. Anderson and A.J. Priestley: Water Research 17(1983), 1227

[3] L.O. Kolarik: Water Research 17 (1983), 141

[4] I. Okuda: Filtration and Separation No. 9-10 (1975), 472

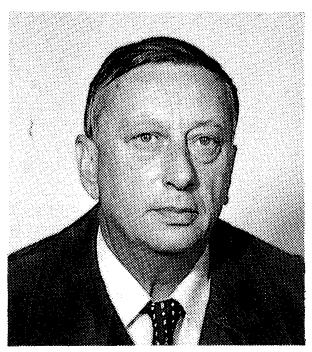

Vladimír Hencl: For biography see Magn. Electr. Separ. 3 (1991), 46

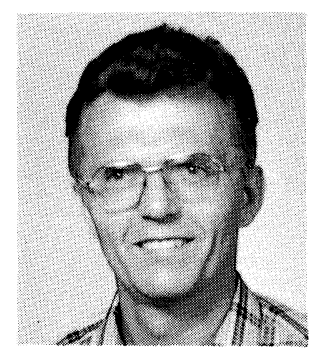

Pavel Mucha: Graduated from the Czech Technical University in Prague, Faculty of Mechanical Engineering, in 1961. After a short spell in industry he joined, in 1963, the Mining Institute (now Institute of Geotechnics) of the Czech Academy of Sciences where he obtained his Ph.D. degree. His main area of interest has been mineral processing, particularly coal preparation. Recently he has been involved in various projects, including dewatering of suspensions, dry cleaning of coals, magnetic separation and filtration and treatment of waste waters.

Keywords: water treatment, magnetic separation, magnetite 